\title{
EMPLOYEE RELATIONSHIP MANAGEMENT: DESAIN, KERANGKA KERJA DAN PENERAPAN TEKNOLOGI INFORMASI DI DALAMNYA (Studi Kasus Perusahaan Multi Nasional di Jakarta-“Company Confidential”)
}

\author{
Yonathan Dri Handarkho" ${ }^{1}$, Adhib Rahmanto ${ }^{2}$ \\ ${ }^{1}$ Fakultas Teknologi Industri, Program Studi Teknik Informatika \\ Universitas Atma Jaya Yogyakarta \\ Email: yonathan_dh@staff.uajy.ac.id \\ ${ }^{2}$ Freelance Business System Analyst/Project Management Consultant \\ Email: adhibr@yahoo.com
}

\begin{abstract}
ABSTRAKS
Dalam rangka meningkatkan performa dan kinerja , banyak perusahaan mencoba untuk membangun sebuah sistem yang didasarkan pada konsep "relationship management" untuk mengelola hubungan yang tercipta dari berbagai pihak yang terkait dengan perusahaan tersebut. Salah satu pihak yang juga memiliki peranan penting di dalam performa dan kinerja dari sebuah perusahaan adalah karyawan. Performa dan kinerja yang baik dari karyawan, akan memberikan dampak yang sangat baik juga bagi performa dan kinerja sebuah perusahaan. Berkaca dari hal tersebut, sudah selayaknya apabila sebuah perusahaan mulai berinvestasi membangun sebuah sistem berbasis relationship management untuk mempertahankan performa dan loyalitas dari karyawan nya. Konsep relationship tersebut dikenal dengan nama Employee Relationship Management (ERM). ERM dapat didefinisikan sebagai pemanfaatan teknologi informasi dalam bidang sumber daya manusia dalam rangka meningkatkan performa dan loyalitas karyawan yang berdampak pada peningkatan performa perusahaan. Dalam studi ini, pembahasan ERM diarahkan kepada area "performance" dan "learning development" dari sebuah perusahaan. Dalam makalah ini penulis mencoba untuk menawarkan konsep secara lebih rinci meliputi kerangka kerja ERM , contoh penerapan dan penggunaan teknologi informasi yang sesuai.
\end{abstract}

Kata kunci: Karyawan, ERM, Sumber daya manusia, performance, learning- development, kerangka kerja

\section{PENDAHULUAN}

Pemanfaatan teknologi informasi oleh sebuah perusahaan pada area relationship management saat ini banyak diarahkan kepada bagaimana menjalin relasi dengan pihak 'eksternal' perusahaan yaitu konsumen. Banyak perusahaan besar menghabiskan banyak sumber daya untuk membangun sistem yang di arahkan pada proses memelihara dan meningkatkan loyalitas dari konsumen. Salah satunya dengan cara menawarkan sebuah layanan yang bersifat responsif kepada konsumen sesuai dengan data konsumen yang dimiliki oleh perusahaan tersebut (Seeman, 2006). Konsep tersebut dikenal dengan nama Costumer Relationship Management (CRM).

Seiring berjalannya waktu, banyak perusahaan yang mulai memperluas jangkauan relationship management dengan mengarahkan fokus tidak hanya kepada konsumen tetapi juga kepada pihak eksternal lain seperti supplier. Diharapkan dengan adanya sebuah sistem yang mengelola relasi dengan supplier, perusahaan akan mampu mengkoordinasikan dan mengotomatisasikan proses yang terkait dengan supplier integration and communication (Lang dkk., 2002). Sistem tersebut dikenal dengan nama Supplier Relationship Management. Dan masih terdapat banyak lagi bentuk bentuk dari relationship management lainnya yang terus dikembangkan dan diadopsi kedalam bentuk yang berbeda.

Apabila kita perhatikan, kesamaan dari bentuk relationship management di atas adalah pihak yang dikelola selalu berasal dari eksternal perusahaan. Hal tersebut menjadi wajar karena pihak tersebut merupakan salah satu faktor yang ikut menentukan performa sebuah perusahaan. Akan tetapi perlu untuk dipahami bahwa terdapat pihak lain yang juga memiliki peranan yang tidak kalah penting terhadap kinerja dari sebuah perusahaan yang berasal dari internal perusahaan. Pihak tersebut mengacu kepada salah satu aset paling berharga dari sebuah perusahaan, yaitu karyawan (Employee).

Karyawan adalah salah satu faktor penting dari kesuksesan sebuah perusahaan. Semakin bagus dan maksimal kinerja dari karyawan, akan memberikan dampak yang sangat positif bagi sebuah perusahaan. Berkaca dari hal tersebut, ada baiknya perusahaan juga mulai berinvestasi untuk membangun sebuah sistem relationship management untuk memelihara kinerja dan loyalitas dari karyawannya, seperti halnya kepada pihak konsumen maupun supplier. Hal tersebut dikarenakan karyawaan akan bekerja untuk perusahaan dalam jangka waktu yang cukup lama. Berbeda dengan konsumen maupun supplier yang bisa datang silih berganti (Pieterse, 2008). Konsep relationship management yang mengelola jenis relasi di atas di sebut dengan Employee Relationship Management.

Employee Relationship Management atau disingkat ERM dapat didefinisikan sebagai pemanfaatan teknologi informasi pada area human 
resources dalam rangka meningkatkan kinerja dan loyalitas karyawan yang berdampak pada peningkatan performa perusahaan tersebut. Perlu diketahui bahwa area human resources sendiri mencakup wilayah yang sangat luas. Pada penelitian kali ini, sasaran dari ERM lebih di arahkan kepada dua area dari human resources yaitu area performance dan area learning and development. Pada penelitian ini penulis mencoba menawarkan konsep ERM secara lebih mendetail meliputi kerangka kerja (framework), contoh penerapan, dan penggunaan teknologi informasi yang sesuai pada bidang performance dan learning and development dari sebuah perusahaan.

\section{TINJAUAN PUSTAKA DAN LANDASAN TEORI}

\subsection{Tinjauan Pustaka}

Terdapat beberapa penelitian yang memiliki keterkaitan dengan konsep Employee Relationship Management. Shih, dkk (2011) di dalam jurnalnya yang berjudul "Employee-Organization Relationship and Job Performance” mencoba menjabarkan beberapa teori dan hipotesa mengenai pengaruh dari EmployeeOrganization Relationship (EOR) dan pengaruh positif dari Leader-Member Exchange (LMX) terhadap performa pekerjaan (job performance) karyawan sebuah perusahaan. Liao, dkk (2004) di dalam jurnalnya yang berjudul "Employee relationship and knowledge sharing: a case study of a Taiwanese finance and securities firm" mencoba menganalisa relasi yang terjadi antara karyawan dengan perusahaannya dengan mengambil sebuah studi kasus pada perusahaan di Taiwan. Penelitian tersebut bertujuan untuk melihat dampak apa yang di dapatkan dari relasi yang terbina yang diwujudkan di dalam "knowledge sharing" dan bagaimana pengaruhnya terhadap kinerja sebuah perusahaan. Walaupun kedua jurnal di atas tidak membahas konsep ERM secara langsung, teori dan hipotesa yang dijabarkan pada kedua jurnal tersebut dapat dijadikan sebagai acuan yang dapat dipergunakan untuk mengembangkan konsep relationship di dalam ERM.

Yogcai(2010) dalam jurnal yang berjudul “Employee Relationship Management of Small and Medium-sized Enterprises" mencoba membahas konsep ERM dengan lebih detail. Yogcai mencoba menjabarkan bagaimana peranan ERM dalam Small and Medium-sized Enterprises (SMEs). Dalam jurnal tersebut Yogcai mencoba menujukkan bagaimana SMEs dituntut untuk mulai memberikan perhatian kepada employee relations yang diwujudkan melaui penerapan ERM dalam rangka meningkatkan performa perusahaan.

Berbeda dengan ketiga penelitian di atas yang lebih mengarah kepada penjelasan dasar yang mendukung konsep ERM secara umum serta kegunaannya bagi sebuah perusahaan, penelitian ini lebih ditujukan untuk mendefinisikan konsep ERM dengan lebih spesifik di mulai dari desain kerangka kerja, cakupan penerapan di area human resources sebuah perusahaan, dan penggunaan teknologi informasi yang mendukung kerangka kerja ERM.

Terkait dengan penelitian ini, penawaran desain kerangka kerja dari sebuah konsep relationship management bukan merupakan suatu hal yang baru. Piedade, dkk (2008) pada jurnalnya yang berjudul "Student Relationship Management: Concept, Practice and Technological Support” juga mencoba menawarkan desain dan kerangka kerja dari konsep relationship management yang dikhususkan bagi lingkungan perguruan tinggi yang di kenal dengan nama Student Relationship Management (SRM). Pada jurnal tersebut, Pieadede menjabarkan konsep SRM dengan memberikan gambaran sistem secara umum, arsitektur, strategi, contoh penerapan dan teknologi yang mendukung pengimplementasian SRM.

Pada penelitian ini penulis juga mencoba menjabarkan sistem ERM secara detail dengan mengadopsi pada penjabaran yang dilakukan oleh Piedede, dkk(2008) meliputi kerangka kerja, arsitektur, contoh penerapan dan teknologi yang mendukung pengimplementasian ERM pada sebuah perusahaan.

\subsection{Landasan Teori}

\subsubsection{Definsi ERM}

Secara singkat, ERM bisa didefinisikan sebagai pemanfaatan teknologi informasi pada area human resources dalam rangka meningkatkan kinerja dan loyalitas dari karyawan yang berdampak pada peningkatan performa perusahaan tersebut. Apabila dijabarkan secara lebih umum, ERM merangkul seluruh staff atau karyawan dari semua bagian dan tingkatan perusahaan untuk bisa mewujudkan tujuan dari sebuah perusahaan, salah satunya dengan cara mengimplementasikan berbagai kebijakan yang berlaku dan mengelola relasi dan komunikasi yang terjadi, baik antara perusahaan dengan karyawan ataupun karyawan dengan karyawan (Yongcai,2010).

Secara spesifik, komunikasi dan relasi yang dikelola mengacu kepada terciptanya hubungan timbal balik yang saling menguntungkan antara perusahaan dengan karyawan. Karyawan sebagai salah satu aset perusahaan membantu perusahaan untuk bisa mencapai visi, misi, dan tujuan dari perusahaan yang sudah dicanangkan sebelumnya. Sebaliknya agar karyawan dapat mencapai hal tersebut, perusahaan juga diharapkan membantu karyawan dalam hal professional development, baik dari sisi teknikal maupun non-teknikal. Bentuk implementasi dari pengelolaan relasi tersebut dapat diwujudkan dengan membangun sebuah sistem berbasis teknologi informasi yang akan memudahkan masing masing pihak yang terlibat untuk mengelola relasi yang terjalin di dalamnya. Nantinya sistem tersebut dibangun di bawah area human resources yaitu pada bagian performance dan learning and development dan akan menjadi system owner dari 
sistem ERM.

\subsection{Business Intelligence}

Seperti telah dijelaskan pada bagian sebelumnya, penelitian ini lebih ditujukan untuk mendefinisikan konsep ERM dengan lebih spesifik dan salah satunya adalah penggunaan teknologi informasi yang mendukung kerangka kerja dari ERM. Peran teknologi informasi dalam konsep ERM adalah untuk mengelola data performa dari karyawan yang di nilai berdasarkan masing masing target atau goal yang sudah ditetapkan oleh perusahaan. Di harapkan dari hasil analisa terhadap berbagai data performa tersebut dapat ditarik sebuah pengetahuan yang berguna bagi perusahaan untuk memutuskan tindakan yang tepat sehingga dapat membantu karyawan dalam meningkatkan atau mempertahankan performa yang dimilikinya.

Salah satu bentuk teknologi yang sesuai untuk diintegrasikan dengan konsep ERM terkait dengan pengelolaan relationship management tersebut adalah Business Intelligence. Teknologi Business Intelligence dapat didefinisikan sebagai sebuah sistem yang menggabungkan proses pengumpulan data, penyimpanan data, dan pemerolehan pengetahuan dengan analytical tools untuk menghasilkan sebuah informasi yang bersifat kompleks dan kompetitif untuk pihak yang memerlukannya seperti pihak perencana atau pengambil suatu keputusan (Negash, 2003). Definisi di atas secara tersirat menjelaskan bahwa sebuah sistem Business Intelligence yang ideal mampu untuk menyediakan sebuah informasi yang bersifat actionable pada waktu yang tepat, di lokasi yang tepat, dan dalam bentuk yang tepat juga, untuk membantu sebuh pihak dalam membuat keputusan (Negash, 2003). Penerapan teknologi Business Intelligence pada konsep ERM akan dijabarkan lebih dalam pada bagian pembahasan.

\section{METODOLOGI PENELITIAN}

\subsection{Bahan Penelitian}

Seperti yang telah dijabarkan sebelumnya, konsep Employee Relationship Management (ERM) memiliki kaitan yang erat dengan area kerja human resources dari suatu perusahaan. Pada penelitian kali ini, pembangunan desain kerangka kerja (framework) ERM di fokuskan pada bagian performance dan bagian learning and development yang didasarkan pada area human resources dari sebuah perusahaan multi nasional di Jakarta.

\subsection{Analisa Performance dan Learning and Development Area}

\subsubsection{Performance}

Area Performance adalah salah satu area kerja di dalam human resources dari sebuah perusahaan yang bisa dibagi kedalam empat tahap sebagai berikut:

\section{Performance Planning}

Performance Planning diawali dengan menentukan target yang hendak dicapai oleh suatu perusahaan. Pada awal tahun, perusahaan akan mendistribusikan goal yang akan dijadikan acuan dalam memberikan sebuah penilaian terhadap kinerja dari karyawan. Goal tersebut didistribusikan secara global dan akan di ikuti ataupun di adopsi oleh masing-masing kantor cabang, disesuaikan dengan kebutuhan dan karakteristik dari masing masing kantor cabang dalam rangka mendukung goal perusahaan secara global.

Terkait dengan aliran relasi yang terjadi, pada area ini karyawan memberikan dukungan (support) kepada departemen di mana karyawan ditempatkan. Selanjutnya departemen akan memberikan dukungan kepada kantor cabang, dan kantor cabang akan memberikan dukungan kepada kantor pusat (global) dalam hal mencapai goal dari perusahaan. Gambar 1 menunjukkan aliran dukungan antar level perusahaan dalam rangka mencapai goal perusahaan yang merupakan salah satu wujud relasi yang terbentuk pada area ini.

Di dalam Performance Planning, setiap goal atau objective dapat dikelompokkan sesuai dengan kategori yang ditentukan oleh sebuah perusahaan seperti: Business Ethic, Discipline, Financial Responsibility, Integrity, Team Work Environment, dan lainnya, tergantung dari kebijakan perusahaan.

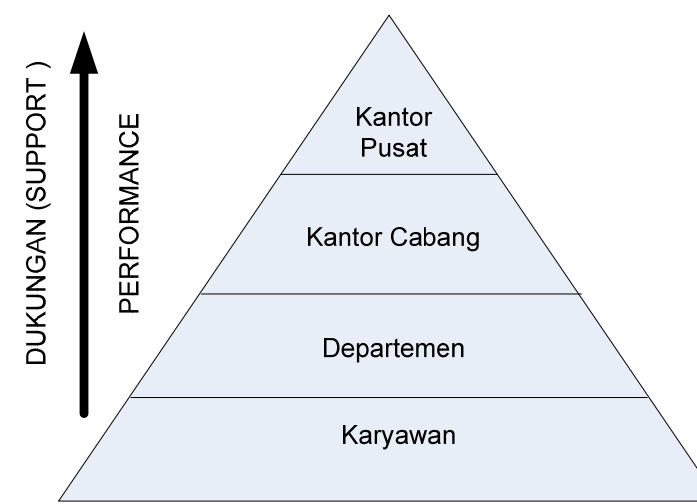

Gambar 1. Bagan relasi dalam performance planning

\section{Feedback and Coaching}

Dalam tahap ini, karyawan membuat suatu langkah atau rencana yang akan dilakukan untuk bisa mencapai goal yang sudah ditentukan di dalam tahap performance planning, serta menentukan pengukuran kuantitatif sebagai bentuk pencapaian goal tersebut. Contoh sederhana terkait dengan goal pada kategori discipline, dapat digunakan pengukuran kuantitatif sebagai berikut: karyawan tidak akan datang terlambat ke kantor lebih dari dari dua kali dalam satu tahun. Tentu saja pada tahapan ini, karyawan perlu untuk berdiskusi dengan atasan atau manager dalam menentukan ukuran yang akan digunakan.

\section{Assessment and Review}

Tahapan yang ketiga adalah proses review yang dilakukan oleh karyawan bersama dengan atasan 
(supervisor atau manager) atas performa atau tindakan apa saja yang sudah dilakukan, bagaimana status pencapaian goal tersebut, dan kapan goal tersebut tercapai.

\section{Rewards \& Recognition}

Setelah proses Assessment dan Review, tahap terakhir adalah pemberian penghargaan sesuai dengan hasil akhir yang dicapai karyawan baik dalam bentuk bonus, kenaikan gaji, promosi atau sesuai dengan ketentuan yang berlaku di perusahaan.

\subsubsection{Learning and Development}

Area Learning and Development dapat dibagi menjadi tiga tahapan sebagai berikut:

\section{Development Planning}

Bersamaan dengan berjalannya tahap Performance Planning dari area Performance, karyawan akan membuat sebuah Development Planning yang terdiri dari pengalaman, pengetahuan, atau skill yang dibutuhkan serta bagaimana langkah yang akan dilakukan untuk mendukung tercapainya skill tersebut seperti on-job-training, assignments, training, dan lain lain. Terkait dengan hal tersebut, karyawan akan mendapatkan dukungan dari departemen, selanjutnya departemen memperoleh dukungan dari kantor cabang, dan kantor cabang mendapatkan dukungan dari kantor pusat dalam mencapai kebutuhan professional development karyawan seperti ditunjukkan pada Gambar 2. Dalam pembuatan Development Planning tersebut, ekspektasi terhadap experience, knowledge, dan skill juga turut di kelompokkan sesuai dengan kebijakan dari perusahaan seperti Planning and Organizing, Business Process, Technical Growth and Development, Leadership, Communication, dan lain sebagainya.

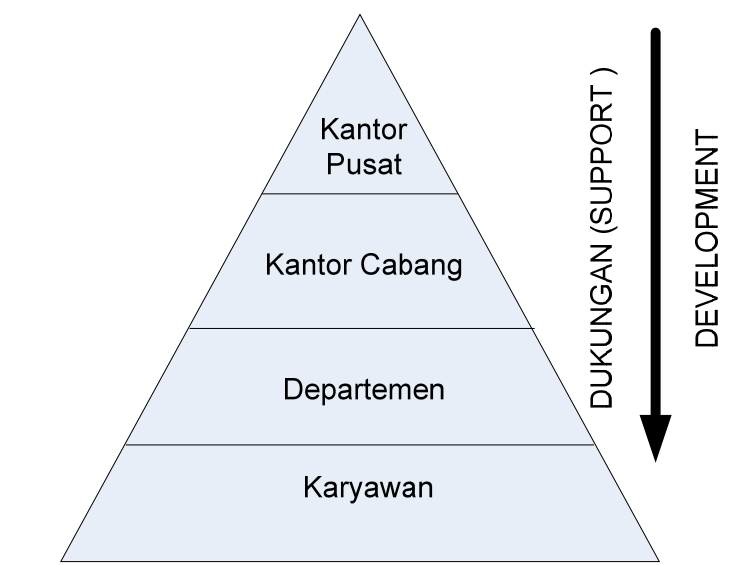

Gambar 2. Bagan relasi dalam development planning

\section{Feedback \& Coaching}

Pada tahap ini, karyawan bersama dengan atasan (supervisor atau manager) akan mendiskusikan Development Planning yang telah dibuat. Diskusi tersebut berfokus kepada langkah-langkah development yang akan diambil yang disesuaikan dengan relevansi dan kompetensi untuk level atau jabatan karyawan yang bersangkutan.

\section{Assessment \& Review}

Tahap yang ketiga adalah proses review yang dilakukan oleh karyawan bersama sama dengan atasan atas apa saja kegiatan yang terkait dengan development yang sudah terlaksana, bagaimana status pencapaian development tersebut, dan kapankah development tersebut tercapai.

Pengolahan dari kedua area kerja human resources di atas (performance dan learningdevelopment) akan memunculkan relasi yang nantinya bisa dikelola untuk membantu meningkatkan performa dari perusahaan dalam mencapai visi dan misi yang diharapkannya. Secara umum terdapat empat bentuk konklusi yang bisa di dapatkan dari relasi yang terjadi sebagai berikut:

- Performance baik dan development baik, maka relasi yang terbentuk antara perusahaan dengan karyawannya bisa dikatakan baik atau berada pada kondisi ideal.

- Performance baik tetapi development tidak berjalan dengan baik, bisa di artikan relasi tidak berjalan dengan seimbang. Hanya saja kondisi tersebut akan menimbulkan sebuah pertanyaan, bagaimana karyawan bisa memenuhi target yang diberikan kepada mereka sedangkan perusahaan tidak bisa memenuhi kewajiban mereka dalam rangka mendukung kinerja dan performa dari karyawan? Apakah dikarenakan karyawannya yang memang benar benar sangat berkualitas? Apakah performa mereka bisa bertahan untuk waktu waktu selanjutnya?

- Performance tidak berjalan dengan baik dan development berjalan dengan baik. Hal tersebut bisa saja terjadi terkait dengan faktor SDM, tetapi bisa dikatakan jarang sekali terjadi.

- Performance tidak berjalan dengan baik dan development tidak berjalan dengan baik. Relasi yang terjadi sungguh sangat buruk dan bisa memberikan efek yang negatif kepada perusahaan. Sehingga bila hal tersebut terjadi harus dilakukan pembenahan baik dari segi manajemen maupun karyawan.

Untuk bisa mengelola relasi yang tercipta dan menghasilkan konklusi dari relasi--relasi tersebut, diperlukan adanya sebuah sistem yang mampu mencatat dan mengelola segala aktifitas yang terjadi di kedua area human resources tersebut. Pada tahap inilah sistem ERM mengambil peranannya. ERM adalah sebuah sistem berbasis teknologi informasi yang mampu mengelola semua relasi dan aktivitas yang terkait dan merangkumnya menjadi sebuah knowledge yang dibutuhkan perusahaan dalam melakukan evaluasi maupun mengambil keputusan terkait dengan performa dari sebuah perusahaan secara keseluruhan baik dari level karyawan sampai dengan manajerial. Teknologi yang tepat untuk 


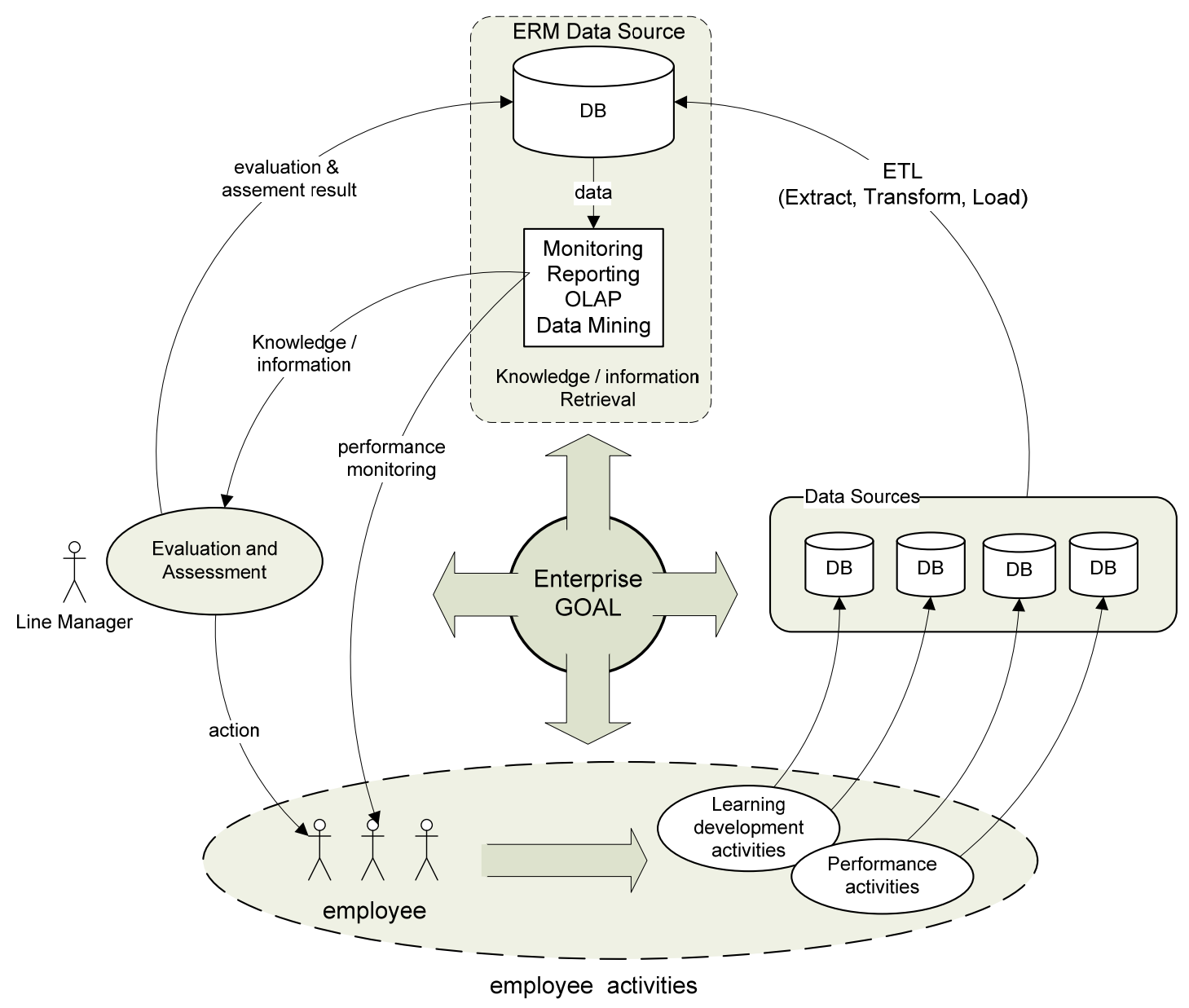

Gambar 3. Kerangka kerja Sistem ERM

menunjang pengimplementasian sistem ERM adalah Business Intelligence (BI). BI sediri dapat didefinisikan sebagai sebuah sistem yang menggabungkan proses pengumpulan data, penyimpanan data dan pemerolehan pengetahuan dengan analytical tools untuk menghasilkan sebuah informasi yang bersifat kompleks dan kompetitif untuk pihak yang memerlukannya (Negash, 2003). Penjelasan mengenai peranan teknologi informasi yaitu business intelligence pada aplikasi ERM akan dijabarkan secara detail pada bagian pembahasan selanjutnya.

\section{PEMBAHASAN}

\subsection{Kerangka Kerja ERM Secara Umum}

Pada penelitian ini, kerangka kerja dari sistem ERM secara umum yang coba di ajukan, dikembangkan berdasarkan hasil analisa dari area performance dan learning development perusahaan, serta di dasari oleh konsep teknologi informasi berbasis business intelligence. Kerangka kerja dari sistem ERM dapat dilihat pada Gambar 3. Pada kerangka kerja tersebut, semua komponen yang terkait didalamnya mengacu pada goal (tujuan) yang ditetapkan oleh perusahaan. Penjelasan dari komponen yang dimunculkan pada gambaran sistem tersebut adalah sebagai berikut:

- Enterprise goal adalah tujuan atau target yang ditetapkan oleh perusahaan yang harus di capai pada setiap periode tertentu. Goal tersebut menjadi pusat dari semua aktivitas yang terjadi didalam siklus hidup ERM. Terkait dengan hal tersebut, ERM berperan membantu perusahaan dalam memonitoring, mengevaluasi, dan juga membantu memperoleh pengetahuan terkait dengan relasi yang terjadi antara perusahaan dengan karyawannya dalam hal memenuhi enterprise goal yang telah ditetapkan di awal. Secara teknis enterprise goal akan dijadikan tolak ukur bagi sistem ERM untuk mengevaluasi performa dari masing masing karyawan apakah sesuai dengan standar yang diharapkan atau tidak.

- Employee Activites adalah komponen yang akan diolah oleh ERM untuk menghasilkan knowledge yang bisa digunakan perusahaan untuk mengelola relasi yang terjadi antara perusahaan dengan karyawannya terkait dengan pencapaian enterprise goal. Komponen employee activites mencakup semua aktifitas yang terkait dengan area performance dan area learning and development dari area human resources perusahaan seperti yang ditunjukkan pada bab 3.2 


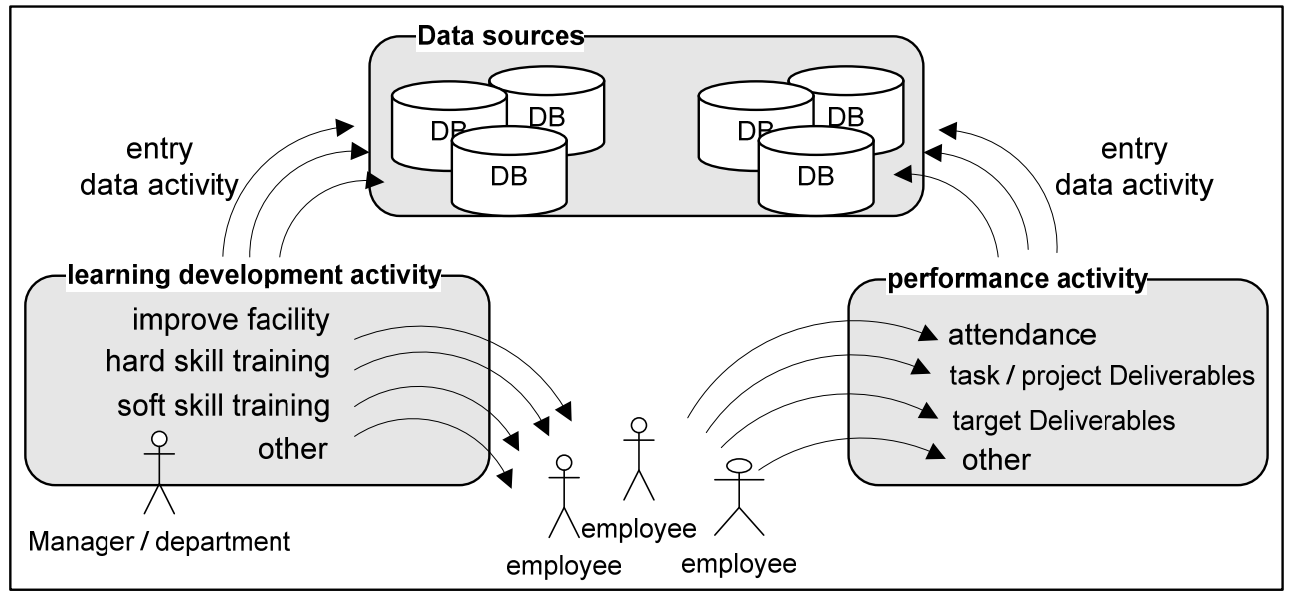

Gambar 4. Komponen Employee Activity

sebelumnya. Pada komponen ini, setiap aktifitas baik pada area performance seperti kehadiran, penyelesaian tugas pekerjaan, pencapaian target pekerjaan, maupun pada area learning and development seperti peningkatan fasilitas, pemberian pelatihan bagi karyawan dan berbagai aktifitas lainnya yang mendukung pencapaian enterprise goal, akan di entry kan pada sistem informasi yang terdapat pada masing masing area aktifitas tersebut. Selanjutnya semua data yang dibutuhkan untuk menganalisa relationship yang ada, akan di ekstrak oleh ERM dari setiap data source yang tersedia. Dengan begitu kita tidak perlu lagi memaksa untuk membangun ulang sebuah sistem baru di setiap bagian area aktivitas apabila telah terdapat sebuah sistem disana sebelumnya. Yang perlu untuk dilakukan selanjutnya adalah bagaimana data source yang tersedia bisa terintegrasi dengan baik yang akan dijabarkan pada komponen selanjutnya dari kerangka kerja ERM. disimpan pada data source dari ERM dan dilakukan proses analisa selanjutnya. Untuk bisa menjalankan proses tersebut dibutuhkan teknologi berbasis business intelligence yang terdiri dari fungsionalitas data extraction, data transformation, dan data loading atau yang dikenal dengan extract, transform, load (ETL).

Data extraction adalah proses yang berhubungan dengan proses mengekstrak data dari berbagai sumber data employee activities. Sumber sumber data tersebut tentu saja memiliki format dan bentuk yang berbeda beda (raw data) sehingga diperlukan teknik yang berbeda untuk melakukan proses ekstraksi data dari beberapa sumber data yang memiliki format tidak seragam (Poniah, 2001).

Data transformation adalah sebuah proses untuk menstandartkan format dari data yang telah diekstrak pada proses data extraction sebelumnya, sehingga di hasilkan sebuah integrasi

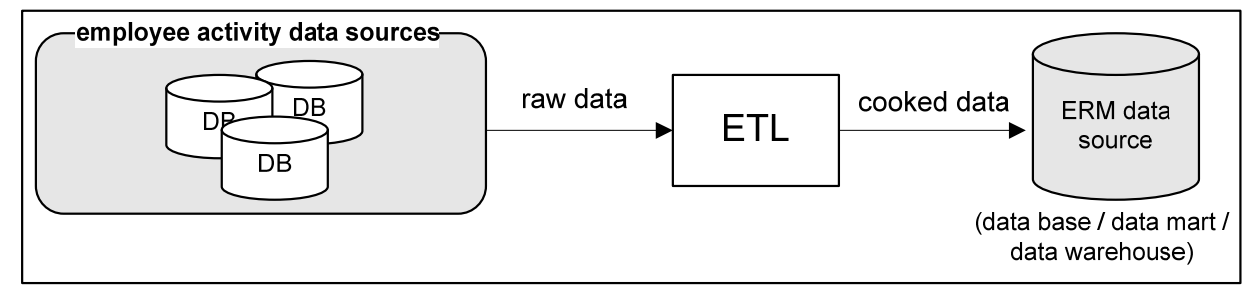

Gambar 5. Komponen ETL (Extract, Transform, Load)

- ETL (Extract, Transform, Load) adalah komponen selanjutnya yang bertugas untuk mengintegrasikan berbagai data dari employee activites yang bisa berasal dari berbagai sumber data yang berbeda. Data yang berasal dari berbagai sumber data yang berbeda beda tentu saja memiliki berbagai perbedaan entah ukuran, tipe, maupun format data. Oleh karena itu sebelum bisa di olah data, data tersebut perlu untuk diubah, dikonversi, dan dipersiapkan dalam format yang telah ditetapkan untuk kemudian data yang jauh lebih steril, terstandarisasi dan sudah terangkum dengan baik (cooked data) (Poniah, 2001). Setelah melalui proses data extraction dan data transformation, maka hal terakhir yang perlu dilakukan adalah memuat data data tersebut kedalam data source dari ERM secara periodik. Proses tersebut dikenal dengan nama data loading. Implementasi data source dari sistem ERM sendiri bisa berupa sebuah data warehouse ataupun data mart. 


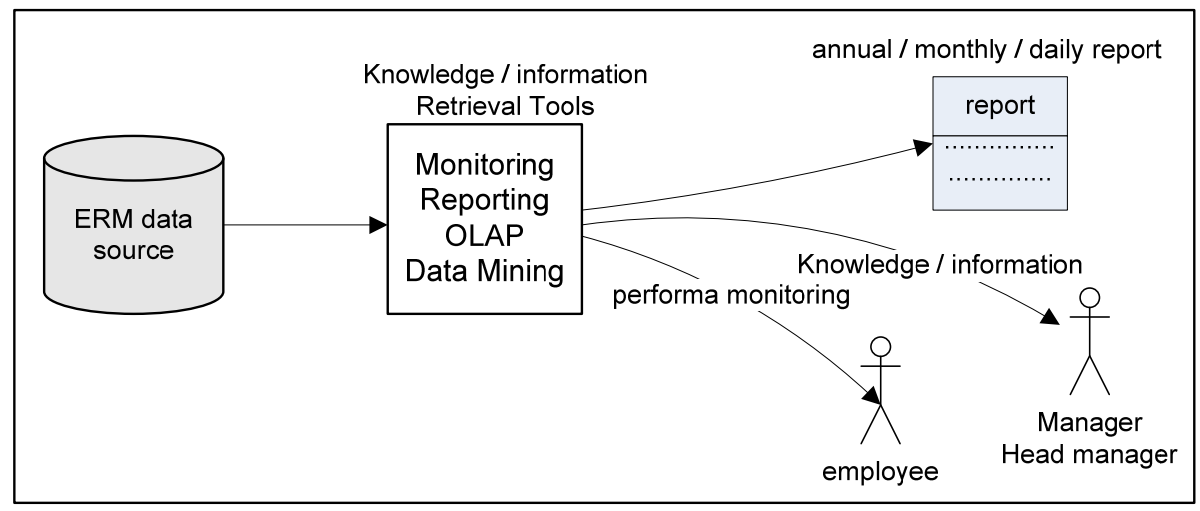

Gambar 6. Komponen knowledge - information retrieval

- Knowledge - information retrieval adalah komponen yang bertugas memberikan laporan monitoring data dari setiap aktivitas di dalam area performance dan learning and development, serta mampu menganalisa data yang tersimpan di data sources ERM untuk diolah menjadi sebuah knowledge yang dapat berguna bagi pihak perusahaan dalam mengelola relasi antara perusahaan dengan karyawannya. Melalui komponen ini, karyawan juga bisa men-tracking atau memonitoring performa dan achievement yang telah di capai selama ini. Untuk bisa memperoleh knowledge yang diharapkan, terdapat beberapa metode pemerolehan knowledge berbasis business intelligence yang dapat digunakan. Metode tersebut antara lain adalah OLAP dan Data Mining.

Online analytical processing atau disingkat dengan OLAP adalah salah satu tools dalam business intelligence yang memungkinkan user untuk mendapatkan informasi yang cepat, konsisten, dan interaktif dengan menggunakan berbagai macam sudut pandang (multidimensi) yang dibutuhkan terhadap informasi tersebut (Poniah, 2001). Sebagai contoh, melalui OLAP, user bisa melihat apakah aktivitas yang dijalankan pada area learning and development sudah berjalan sesuai dengan perencanaan awal.

OLAP memungkin perusahaan untuk memperoleh informasi secara general maupun secara lebih mendetail terhadap aktifitas dari area performance maupun area learning and development dari masing masing karyawan disebuah divisi. Hal tersebut dikarenakan OLAP memiliki kemampuan untuk melakukan roll up (melihat data dengan mengelom- pokkannya secara general), drill down (menjabarkan data dengan lebih detil), slicing-dicing / pivoting (melihat data dari berbagai sudut pandang).

Seperti telah dijelaskan sebelumnya, pendekatan OLAP dalam memperoleh sebuah informasi atau pengetahuan adalah pendekatan yang di arahkan langsung oleh user atau disebut dengan pendekatan user driven. Akan tetapi untuk bisa menemukan knowledge yang lebih mendalam, pemerolehan informasi tidak bisa hanya mengandalkan pendekatan user driven. Sistem ERM harus mampu juga memberikan knowledge yang didapatkan dari hasil analisa terhadap hubungan data data baik dari data masa lalu maupun saat ini. Dalam kasus ini user memerlukan sebuah teknologi yang bisa menemukan sebuah pengetahuan dengan sendirinya. Dalam hal ini pendekatan terhadap permasalah bukan lagi berdasarkan user, tapi berdasarkan data itu sendiri atau disebut dengan data-driven. Di sinilah peran data mining dibutuhkan. Teknologi data mining berpusat pada penemuan fakta fakta baru dan relasi di dalam data. Jika dengan metode query tradisional, user mampu untuk mencari informasi berdasarkan informasi yang telah diketahui sebelumnya, data mining memungkinkan user untuk menemukan informasi yang tersembunyi dengan menggali pola dan kecenderungan dalam data mentah yang sebelumnya tidak diketahui (Poniah, 2001). Hal tersebut tentu saja sangat dibutuhkan perusahaan untuk mengelola relasi yang terjadi pada area performance dan learning development. Sebagai contoh, dengan menganalisa pola pola dari data area learning-development dan relasinya dengan data dari area performance di masa lalu, perusahaan bisa memperoleh pengetahuan mengenai aktifitas learning development yang tepat untuk meningkatkan performa karyawan di masa mendatang. Terdapat berbagai macam metode dalam data mining yang bisa digunakan untuk memperoleh pengetahuan dari sumber data, antara lain klasifikasi, clustering, asosiasi, sekuensi, forecasting, fuzzy logic dan berbagai macam teknik data mining lainnya.

- Evaluation and Assessment adalah komponen terakhir dari kerangka kerja sistem ERM yang ditawarkan pada penelitian kali ini. Pada bagian ini, manajer atau kantor pusat akan mengevaluasi dan memberikan penilaian terhadap performa dari karyawaan terkait dengan pencapaian target atau goal yang sudah diberikan berdasarkan knowledge atau pengetahuan yang diperoleh dari area performance dan learning - development. 


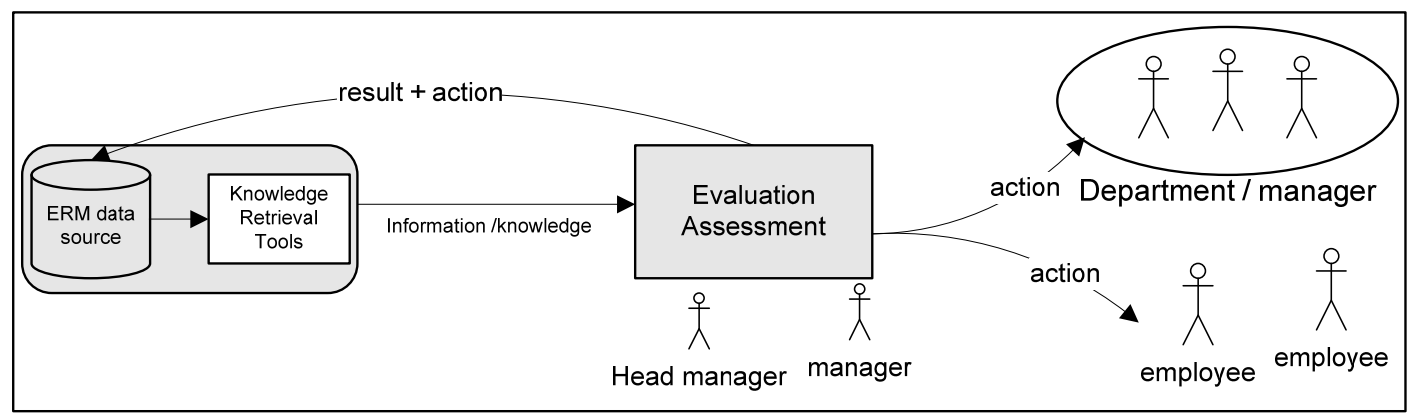

Gambar 7. Evaluation and assessment

Hasil yang diperoleh dari komponen ini akan digunakan sebagai dasar untuk menentukan tindakan yang harus diambil perusahaan selanjutnya seperti melakukan perbaikan apabila ditemukan berbagai kekurangan ataupun pemberian reward kepada karyawan yang dianggap berprestasi. Action atau tindakan bisa langsung di berikan kepada masing masing individu karyawan atau secara luas kepada keseluruhan divisi atau departemen dari perusahaan yang terkait. Sebagai contoh pada divisi penjualan diperoleh hasil yang kurang memuaskan dan tidak mencapai target yang diinginkan di awal. Selanjutnya melalui sistem ERM diketahui bahwa dukungan dari perusahaan (area learning - development ) terhadap divisi ini kurang maksimal, seperti pelatihan yang tidak maksimal, peningkatan fasilitas pendukung tidak sesuai dengan kesepakatan awal, dan lain sebagainya. Berdasarkan informasi tersebut maka perusahaan bisa melakukan tindakan baik berupa pengarahan ataupun teguran kepada departemen atau pihak yang bertanggung jawab pada area learning development untuk memperbaiki kinerja pada area tersebut, agar performa karyawan pada divisi penjualan kedepannya dapat berjalan dengan lebih maksimal. Hal yang tidak boleh dilupakan adalah hasil evaluasi, penilaian dan tindakan yang di ambil, harus dicatat dan disimpan di dalam sistem ERM. Hal tersebut perlu dilakukan karena data tersebut dapat digunakan lagi untuk mendukung proses evaluasi dan penilaian di masa mendatang.

\subsection{Implementasi dan penerapan ERM}

Terdapat berbagai bentuk metode pemerolehan pengetahuan yang bisa diterapkan pada sistem ERM dalam rangka mengevaluasi performa karyawan dari sebuah perusahaan. Sebagai contoh, kita bisa menggunakan metode fuzzy classification juga diperkenalkan oleh Meier, dkk (2005). Fuzzy classification memungkinkan user untuk bisa menggolongkan performa dari karyawan berdasarkan dua aspek penilaian yang bisa diambil dari area performance dan area learning and development. Dari hasil klasifikasi tersebut, perusahaan bisa mengelompokkan performa karyawannya kedalam beberapa kategori atau tingkatan, seperti: Do not Meet Requirement, Minimum Meet Requirement, Meet Requirement, dan Exceed Meet Requirement. Kriteria penilaian sendiri harus sudah disepakati dan diketahui sebelumnya oleh pihak perusahaan dan karyawan. Dari hasil pengelompokaan kinerja ini, perusahaan bisa memperoleh bahan pertimbangan atau informasi pendukung untuk menentukan tindakan apa yang bisa diberikan untuk mendukung kinerja dari karyawannya seperti pemberian rewards, kenaikan jabatan, gaji, training dan rencana fokus karir karyawan kedepannya.

Sistem ERM sendiri di implementasikan dalam format web based. Hal tersebut di karenakan konsep dari ERM adalah mengintegrasikan berbagai sistem dan source data dari berbagai macam departement perusahaan sehingga web based menjadi solusi yang lebih tepat. Terdapat berbagai macam tools pemrogramaan yang dapat digunakan untuk mengembangkan ERM. Salah satu tools yang mendukung pengembangan aplikasi berbasis integrasi enterprise adalah ASP.NET sebagai tools pembangunan aplikasi web dan Microsoft $S Q L$ Server sebagai tools untuk membangun data source, analysis, OLAP, Data Mining dan reporting. Pemilihan tools sendiri harus didasari oleh technological environment dan infrastructure support yang telah ada di dalam sebuah organisasi dan mendukung konsep ERM secara menyeluruh.

\section{KESIMPULAN}

Pengelolaan sebuah relationship oleh perusahaan bertujuan untuk memperoleh knowledge yang dapat digunakan untuk meningkatkan performa dari sebuah perusahaan. ERM adalah salah satu bentuk relationship management yang mengelola relasi yang terjadi antara perusahaan dengan karyawaannya. Di harapkan melalui bentuk relationship management ini, perusahaan dapat membantu karyawannya dalam mencapai performa yang maksimal.

Melalui desain dan kerangka kerja ERM yang di tawarkan pada penelitian ini, di harapkan dapat membantu dan memberikan gambaran bagaimana konsep ERM diimplementasikan di sebuah perusahaan terutama pada wilayah human resources. Untuk kedepannya, terkait dengan penelitian di bidang ERM, dapat difokuskan kepada metode yang 
dapat dipergunakan untuk memperoleh pengetahuan dari relasi yang dikelola oleh ERM.

\section{PUSTAKA}

Liao, Shu-hsien; Chang, Juo-chiang; Cheng, Shih-chieh; Kuo, Chia-mei. 2004. "Employee relationship and knowledge sharing: a case study of a Taiwanese finance and securities firm”. Knowledge Management Research \& Practice (2004) 2: 24 - 34

Lang, André; Paravicini, Daniel; Pigneur,Yves; Revaz, Eric. 2002."From Customer Relationship Management (CRM) to Supplier Relationship Management (SRM)".HEC Lausanne(2002).

Meier, Andreas; Werro, Nicolas; Albrecht, Martin; \& Sarakinos, Miltiadis. 2005. "Using a Fuzzy Classification Query Language for Customer Relationship Management”. Proceedings of the 31st International Conference on Very Large Data Bases, VLDB 2005, Trondheim, Norway, August 2005.

Negash, Solomon \& Gray,Paul. 2003. "Business Intelligence". Ninth Americas Conference on Information Systems.

Piedade, Maria Beatriz; \& Santos, Maribel Yasmina. 2008. "Student Relationship Management: Concept, Practice and Technological Support”. This paper appears in Engineering Management Conference, 2008. IEMC Europe 2008. IEEE International

Pieterse, Jurgens. 2008."Why Employee Relationship Management?", (Online), (http://it.toolbox.com/blogs/enterprisedesign/why-employee-relationship-management21687, diakses 24 Juni 2011)

Ponniah, Paulraj. 2001. "Data Warehousing Fundamentals: A Comprehensive Guide for IT Professionals”. John Wiley \& Sons, Inc.

Seeman, Elaine D. \& O'Hara, Margaret. 2006. "Customer Relationship Management in Higher Education". Campus-Wide Information Systems, vol. 23, pp. 24-34.

Shih, Hsi-An; Hsu, Chu-Chun; Tsay, Hui-Wen. 2011. "Employee-Organization Relationship and Job Performance”. IEEE Int'l Technology Management Conference.

Turban,Efraim; Aronson, Jay E.; \& Liang, Ting Pen. 2005. Decision Support Systems and Intelligent Systems. Dwi Prabantini (Penterjemah). Yogyakarta: Penerbit Andi.

Yongcai, Yan. 2010. "Employee Relationship Management of Small and Medium-sized Enterprises". 2010 International Conference on EBusiness and E-Government. 